$2 \begin{aligned} & \text { Pesquisa Florestal Brasileira } \\ & \text { Brazilian Journal of Forestry Research } \\ & \text { www.cnpf.embrapa.br/pfb }\end{aligned}$

\title{
Micropropagação de espécies florestais brasileiras
}

\author{
Leandro Silva de Oliveira ${ }^{1}$, Poliana Coqueiro Dias², Gilvano Ebling Brondani ${ }^{3}$ \\ ${ }^{1}$ Universidade de São Paulo, Escola Superior de Agricultura "Luiz de Queiroz", Av. Pádua Dias, n 11, CEP 13418-900 , Piracicaba, SP, Brasil \\ 2Universidade Federal de Viçosa, Av. P.H. Rolfs, s/nº, CEP 36570-000, Viçosa, MG, Brasil \\ ${ }^{3}$ Universidade Federal de Mato Grosso, Av. Fernando Corrêa da Costa, n 2367, CEP 78060-900, Cuiabá, MT, Brasil
}

*Autor correspondente:

leandrooliveiraufv@yahoo.com.br

Termos para indexação:

Clonagem

Regeneração in vitro

Cultura de tecidos vegetais

Index terms:

Cloning

In vitro regeneration

Plant tissue culture

Histórico do artigo:

Recebido em 02/02/2013

Aprovado em 12/12/2013

Publicado em 31/12/2013

doi: 10.4336/2013.pfb.33.76.481
Resumo - A micropropagação apresenta um enorme potencial de aplicação para a multiplicação de genótipos de espécies florestais brasileiras de interesse. Os estudos relativos ao cultivo in vitro de tais espécies estão relacionados, principalmente, a ausência de resposta morfogênica às demais técnicas de propagação bem como, a conservação in vitro de germoplasma. A micropropagação via proliferação de gemas axilares corresponde ao principal sistema de propagação in vitro utilizado para a multiplicação de genótipos selecionados, em razão da maior simplicidade ao comparar com a organogênese e embriogênese somática. Entretanto, em vista das espécies florestais nativas serem pouco estudadas, os avanços quanto a propagação in vitro ainda são poucos expressivos. Dessa forma, é necessária a condução de novos trabalhos para promover avanços do cultivo in vitro nestas espécies, bem como o desenvolvimento de novas composições de meios de cultura, testar a interação de reguladores de crescimento ou, até mesmo, sistemas de biorreatores, buscando assim, consolidar a técnica de micropropagação como estratégia aplicável na silvicultura de espécies nativas.

\section{Micropropagation of Brazilian forest species}

\section{Introdução}

No Brasil, a madeira e outros produtos nãomadeireiros obtidos a partir das espécies florestais da flora brasileira são obtidos quase que exclusivamente da exploração das florestas naturais (Plano..., 2006). Por exemplo, os segmentos de madeira serrada e, mesmo o de carvão vegetal, dependem em grande parte do abastecimento de matéria-prima por parte das formações florestais nativas (Fick, 2007; Shimizu, 2007). Em consequência, a exploração indiscriminada das florestas nativas tem posto muitas espécies e, até mesmo populações em risco de extinção, como por exemplo, Araucaria angustifolia (Sousa \& Aguiar, 2012), Swietenia macrophylla (Silva et al., 2004) e Dalbergia nigra (Sartor et al., 2013). Dessa forma, são essenciais estudos visando o aperfeiçoamento de técnicas de multiplicação em larga escala de espécies nativas para 
aplicação em plantios homogêneos, recuperação de áreas degradadas, melhoramento genético e conservação de germoplasma.

A propagação da maioria das espécies florestais é realizada via seminal, principalmente, devido à ausência de informações silviculturais destas espécies (Dias et al., 2012) e pela maior facilidade operacional e menores custos de produção que o método apresenta. No entanto, há problemas quanto à propagação seminal de várias espécies florestais nativas devido à baixa porcentagem de germinação, que muitas vezes é decorrente da dormência das sementes (Ferrari et al., 2004). Acrescenta-se ainda, dificuldades de obtenção e coleta de sementes em quantidade suficiente para a produção de mudas (Debnath, 2004), pois muitas espécies produzem quantidades variáveis e em intervalos irregulares ao longo do tempo, aliado ao desconhecimento sobre a fenologia das espécies florestais nativas (Viani \& Rodrigues, 2007), fatores que acarretam em longo período de tempo para a produção da muda (Nepomuceno et al., 2009).

A falta de sementes melhoradas geneticamente, ou pouco conhecimento tecnológico disponível a respeito da silvicultura da maior parte das espécies nativas e a falta de disponibilização dos conhecimentos vindos das poucas iniciativas de plantio, ainda não permitem a adoção de medidas extensivas que possam estimular e favorecer novos empreendimentos sem incorrer em potenciais riscos (Plano..., 2006). Dessa forma, a propagação vegetativa apresenta-se como alternativa de multiplicação no que se refere às dificuldades na propagação seminal de espécies florestais nativas, tanto ao considerar as finalidades comerciais quanto a conservação de recursos genéticos.

No Brasil, as pesquisas relativas à clonagem de espécies florestais nativas ainda contemplam poucas espécies e técnicas de clonagem (Santos et al., 2011). Atualmente, as aplicações da micropropagação de espécies nativas destinam-se, principalmente, aos genótipos considerados de difícil multiplicação pelos tradicionais métodos de propagação (Fick, 2007; Pelegrini et al., 2011), aos que produzem metabólitos secundários de interesse farmacológico (Fumagali et al., 2008), a conservação de germoplasma in vitro de espécies que se encontram ameaçadas de extinção (Nunes et al., 2003; Noleto \& Silveira, 2004; Souza \& Pereira, 2007; Malosso et al., 2012), bem como ao desenvolvimento de técnicas de biologia molecular (Xavier et al., 2013; Sobha et al., 2003). Esta revisão aborda as pesquisas relacionadas com a micropropagação de espécies nativas, bem como, as perspectivas e tendências de aplicação de novas técnicas biotecnológicas.

\section{Micropropagação de espécies florestais nativas}

A propagação in vitro pode constituir uma alternativa econômica adequada em relação aos métodos clássicos de propagação de espécies florestais nativas, pois além de oferecer a possibilidade de propagação de árvores selecionadas, possibilita a limpeza clonal, obtendo-se plantas livres de vírus por meio de ápices caulinares e meristemas, superando problemas de contaminação patogênica (Wendling et al., 2006). Além disso, a alta taxa de multiplicação acelera os programas de propagação clonal, fato que possibilita a propagação vegetativa de genótipos de alto valor comercial e de difícil enraizamento (Teixeira, 2001).

Segundo dados do Serviço Florestal Brasileiro (2012) no Brasil há cerca de 7.880 espécies florestais arbóreas. Apesar desse elevado o número das pesquisas em relação a micropropagação de espécies florestais nativas ainda são reduzidas. No entanto, deve-se considerar a importância destes trabalhos, os quais podem contribuir significativamente para a produção comercial de espécies de elevado interesse, possibilitando sua multiplicação rápida em larga escala e em curto espaço de tempo.

Dentre os principais problemas existentes na micropropagação, ressalta-se a recalcitrância de várias espécies nativas ao cultivo in vitro e a contaminação por microrganismos (tanto exógena quanto endógena), representando limitações ao estabelecimento das culturas em condições in vitro (Xavier et al., 2013). Além disso, as respostas das plantas às técnicas de micropropagação são variáveis, e dependem da espécie, variedade e/ou cultivar, época de coleta, tipo de explante utilizado e condições de cultivo (Wendling et al., 2006).

A micropropagação de espécies florestais pode ser realizada via proliferação de gemas axilares, organogênese e embriogênese somática (Xavier et al., 2013). A variabilidade genética entre espécies e dentro da mesma espécie pressupõe o ajuste da metodologia para cada material genético, o que torna o processo demorado, e em certas ocasiões, oneroso (Wendling et al., 2006). A micropropagação pela proliferação de gemas axilares provenientes de explantes obtidos tanto de plântulas como de material adulto, corresponde ao método mais utilizado na propagação in vitro de várias espécies lenhosas (Tabela 1). 
Tabela 1. Exemplo de espécies florestais nativas do Brasil propagadas in vitro sob diferentes sistemas de micropropagação.

\begin{tabular}{|c|c|c|c|c|}
\hline Espécies & Explante & Nome comum & Sistema de micropropagação & Referência \\
\hline Acca sellowiana & embriões zigóticos & goiabeira serrana & embriogênese somática & Booz \& Pescador (2007) \\
\hline Acrocomia aculeata & embriões zigóticos & macaúba & embriogênese somática & Moura et al. (2008) \\
\hline Amburana acreana & segmentos nodias & cerejeira & proliferação de gemas axilares & $\begin{array}{l}\text { Fermino Junior \& } \\
\text { Pereira (2012) }\end{array}$ \\
\hline $\begin{array}{l}\text { Anadenanthera } \\
\text { colubrina var. cebil }\end{array}$ & plântulas & angico & proliferação de gemas axilares & $\begin{array}{l}\text { Nepomuceno et al. } \\
\text { (2009) }\end{array}$ \\
\hline Aniba rosaeodora & $\begin{array}{l}\text { embriões zigóticos } \\
\text { gemas apicais }\end{array}$ & pau-rosa & proliferação de gemas axilares & Handa et al. (2005) \\
\hline Araucaria angustifolia & embriões zigóticos & araucária & embriogênese somática & $\begin{array}{l}\text { Astarita \& Guerra (2000) } \\
\text { Santos et al. (2002) }\end{array}$ \\
\hline $\begin{array}{l}\text { Aspidosperma } \\
\text { ramiflorum }\end{array}$ & segmentos apicais & guatambu-amarelo & proliferação de gemas axilares & Hubner et al. (2007) \\
\hline $\begin{array}{l}\text { Aspidosperma } \\
\text { polyneuron }\end{array}$ & segmentos nodais & peroba-rosa & proliferação de gemas axilares & Ribas et al. (2005) \\
\hline Cabralea canjerana & segmentos nodais & canjarana & proliferação de gemas axilares & Rocha et al. (2007) \\
\hline Caesalpinia echinata & foliólulos & pau-brasil & calogênese $^{1}$ & $\begin{array}{l}\text { Werner et al. (2007; } \\
\text { 2009) }\end{array}$ \\
\hline Caesalpinia pyramidalis & $\begin{array}{l}\text { segmentos apicais } \\
\text { segmentos nodais } \\
\text { plântulas }\end{array}$ & catingueira & proliferação de gemas axilares & Silva et al. (2012) \\
\hline Caryocar brasiliense & segmentos nodais & pequizeiro & proliferação de gemas axilares & Santos et al. (2006) \\
\hline Cedrela fissilis & segmentos nodais & cedro & proliferação de gemas axilares & $\begin{array}{l}\text { Nunes et al. (2002), } \\
\text { Amaral (2006) }\end{array}$ \\
\hline Cedrela odorata & segmentos apicais & cedro & proliferação de gemas axilares & Saldanha et al. (2010) \\
\hline Celtis sp. & segmentos nodais & juazeiro-de -bode & proliferação de gemas axilares & Sato et al. (2001) \\
\hline Cordia trichotoma & plântulas & louro-pardo & proliferação de gemas axilares & $\begin{array}{l}\text { Fick et al. (2007), } \\
\text { Heberle (2010) }\end{array}$ \\
\hline Cordia trichotoma & segmentos nodais & louro-pardo & proliferação de gemas axilares & Mantovani et al. (2001) \\
\hline Dalbergia nigra & $\begin{array}{l}\text { segmentos apicais } \\
\text { segmentos nodais }\end{array}$ & jacarandá da Bahia & proliferação de gemas axilares & Sartor et al. (2013) \\
\hline $\begin{array}{l}\text { Didymopanax } \\
\text { morototoni }\end{array}$ & $\begin{array}{l}\text { raiz } \\
\text { caule } \\
\text { nódulo foliar } \\
\text { folha cotiledonar }\end{array}$ & morototó, caixeta & embriogênese somátca & Franco et al. (2006) \\
\hline Erythrina velutina & plântulas & mulungu & proliferação de gemas axilares & Costa et al. (2010) \\
\hline Eugenia involucrata & $\begin{array}{l}\text { segmentos apicais } \\
\text { segmentos nodais }\end{array}$ & $\begin{array}{l}\text { cerejeira-do-rio- } \\
\text { grande }\end{array}$ & proliferação de gemas axilares & Golle et al. (2012) \\
\hline Eugenia pyriformis & segmentos nodais & uvaieira & proliferação de gemas axilares & $\begin{array}{l}\text { Nascimento et al. } \\
\text { (2008a, 2008b) }\end{array}$ \\
\hline Guazuma crinita & plântulas & bolaina blanca & proliferação de gemas axilares & Maruyama et al. (1996) \\
\hline Guazuma crinita & raízes e pecíolos & & organogênese & Maruyama et al. (1997) \\
\hline Hancornia speciosa & $\begin{array}{l}\text { plântulas } \\
\text { segmentos nodais }\end{array}$ & mangaba & $\begin{array}{l}\text { organogênese } \\
\text { proliferação de gemas axilares }\end{array}$ & $\begin{array}{l}\text { Soares et al. (2007) } \\
\text { Sá (2009), Lédo et al. } \\
(2007,2011), \text { Sá et al. } \\
(2012)\end{array}$ \\
\hline $\begin{array}{l}\text { Handroanthus } \\
\text { impetiginosus }\end{array}$ & epicótilos & ipê rosa & proliferação de gemas axilares & Larraburu et al. (2012) \\
\hline Ilex paraguariensis & $\begin{array}{l}\text { embriões zigóticos } \\
\text { segmentos nodais }\end{array}$ & erva-mate & $\begin{array}{l}\text { proliferação de gemas axilares } \\
\text { proliferação de gemas axilares }\end{array}$ & $\begin{array}{l}\text { Horbach et al. (2011) } \\
\text { Santos \& Wendling } \\
(2010)\end{array}$ \\
\hline
\end{tabular}

${ }^{1}=$ desenvolvimento de desorganizado de células, sem a formação de órgãos. 
Tabela 1. Continuação.

\begin{tabular}{|c|c|c|c|c|}
\hline Espécies & Explante & Nome comum & Sistema de micropropagação & Referência \\
\hline Jacaranda decurrens & segmentos nodais & carobinha & proliferação de gemas axilares & Malosso et al. (2012) \\
\hline Luehea divaricata & $\begin{array}{l}\text { segmentos apicais } \\
\text { segmentos nodais } \\
\text { fragmentos foliares } \\
\text { segmentos nodais }\end{array}$ & açoita-cavalo & proliferação de gemas axilares & Flôres et al. (2011) \\
\hline Maclura tinctoria & segmentos nodais & taiúva & proliferação de gemas axilares & Gomes et al. (2010) \\
\hline Miconia sp. & $\begin{array}{l}\text { segmentos nodais } \\
\text { folhas }\end{array}$ & jacatirão & organogênese & Cid et al. (1997) \\
\hline $\begin{array}{l}\text { Mimosa } \\
\text { caesalpiniaefolia }\end{array}$ & $\begin{array}{l}\text { segmentos apicais } \\
\text { segmentos nodais }\end{array}$ & sabiá & proliferação de gemas axilares & Oliveira et al. (2007) \\
\hline $\begin{array}{l}\text { Myracrodruon } \\
\text { urundeuva }\end{array}$ & $\begin{array}{l}\text { segmentos apicais } \\
\text { segmentos nodais }\end{array}$ & aroeirinha & proliferação de gemas axilares & Andrade et al. (2000) \\
\hline Myrciaria aureana & cotilédones & jabuticaba & embriogênese somática & Motoike et al. (2007) \\
\hline Moringa oleifera & $\begin{array}{l}\text { plântulas } \\
\text { ápices caulinares }\end{array}$ & moringa & proliferação de gemas axilares & Cysne (2006) \\
\hline Myrcianthes pungens & segmentos apicais & gabijuzeiro & proliferação de gemas axilares & Souza et al. (2011) \\
\hline Ocotea odorifera & embriões zigóticos & canela sassafrás & proliferação de gemas axilares & $\begin{array}{l}\text { Silva et al. (2001), } \\
\text { Moritz et al. (2009) }\end{array}$ \\
\hline Ocotea catharinensis & embriões zigóticos & canela preta & proliferação de gemas axilares & Moritz et al. (2009) \\
\hline Ocotea porosa & $\begin{array}{l}\text { embriões zigóticos } \\
\text { segmentos apicais }\end{array}$ & imbuia & proliferação de gemas axilares & $\begin{array}{l}\text { Moritz et al. (2009) } \\
\text { Pelegrini et al. (2011) }\end{array}$ \\
\hline Parapiptadenia rigida & plântulas & angico-vermelho & proliferação de gemas axilares & $\begin{array}{l}\text { Kielse et al. (2009), } \\
\text { Nascimento (2008) }\end{array}$ \\
\hline \multirow[t]{2}{*}{ Peltophorum dubium } & $\begin{array}{l}\text { segmentos apicais } \\
\text { segmentos nodais }\end{array}$ & canafístula & proliferação de gemas axilares & Bassan et al. (2006) \\
\hline & epicótilo & & & Curti (2011) \\
\hline Plathymenia reticulada & $\begin{array}{l}\text { segmentos } \\
\text { cotiledonares } \\
\text { segmentos nodais }\end{array}$ & vinhático & proliferação de gemas axilares & Moura et al. (2012) \\
\hline $\begin{array}{l}\text { Schizolobium parayba } \\
\text { var. amazonicum }\end{array}$ & eixos embrionários & paricá & proliferação de gemas axilares & Reis et al. (2009) \\
\hline $\begin{array}{l}\text { Schizolobium } \\
\text { amazonicum }\end{array}$ & segmentos nodais & paricá & proliferação de gemas axilares & Cordeiro et al. $(2004 a, b)$ \\
\hline Sebastiania schottiana & segmentos nodais & sarandi & proliferação de gemas axilares & $\begin{array}{l}\text { Deschamps \& Pinto. } \\
\text { (1995) }\end{array}$ \\
\hline $\begin{array}{l}\text { Stryphnodendron } \\
\text { polyphythum }\end{array}$ & $\begin{array}{l}\text { segmentos } \\
\text { cotiledonares }\end{array}$ & barbatimão & proliferação de gemas axilares & França et al. (1995) \\
\hline \multirow[t]{5}{*}{ Swietenia macrophylla } & plântulas & mogno & proliferação de gemas axilares & Couto et al. (2004) e \\
\hline & $\begin{array}{l}\text { segmentos apicais e } \\
\text { nodais }\end{array}$ & mogno & proliferação de gemas axilares & Lameira et al. (2005) \\
\hline & $\begin{array}{l}\text { segmentos nodais } \\
\text { epicótilo e folhas }\end{array}$ & mogno & $\begin{array}{l}\text { proliferação de gemas axilares } \\
\text { calogênese }^{1}\end{array}$ & Pinto (2012) \\
\hline & epicótilo & mogno & calogênese $^{1}$ & Brunetta et al. (2006) \\
\hline & folhas e raízes & mogno & calogênese $^{1}$ & Rocha \& Quoirin (2004) \\
\hline $\begin{array}{l}\text { Theobroma } \\
\text { grandiflorum }\end{array}$ & botões florais & cupuaçu & proliferação de gemas axilares & Ferreira et al. (2009) \\
\hline
\end{tabular}

${ }^{1}=$ desenvolvimento de desorganizado de células, sem a formação de órgãos. 


\section{Etapas da micropropagação das espécies florestais}

A micropropagação é realizada segundo um determinado procedimento padrão, no qual os explantes oriundos de material vegetal coletado no campo ou em casa de vegetação passam por uma limpeza e desinfestação prévia ao estabelecimento in vitro (Dutra et al., 2009). Após o estabelecimento in vitro, os explantes são multiplicados, alongados, enraizados in vitro ou ex vitro, e por último, aclimatizados em ambiente ex vitro.

Os diferentes trabalhos publicados de micropropagação das espécies florestais brasileiras se restringem apenas às primeiras fases da micropropagação, que incluem o estabelecimento e a multiplicação in vitro. Provavelmente, um dos fatores que restringe o desenvolvimento de protocolos de micropropagação para as espécies corresponde à especificidade de resposta dos genótipos no cultivo in vitro (Sobrosa \& Corder, 2003). Além disso, a própria variabilidade dos explantes, por ser na maioria dos trabalhos de origem seminal, constitui em uma barreira ao cultivo in vitro, exigindo ajustes específicos nas etapas da micropropagação dos genótipos.

\section{Estabelecimento in vitro}

$\mathrm{O}$ estabelecimento in vitro corresponde à fase mais crítica para a maioria das plantas lenhosas (Fermino Junior et al., 2009), principalmente quando se utiliza matrizes adultas selecionadas a campo, devido aos propágulos apresentarem altas taxas de contaminação. Dessa forma, os principais aspectos que devem ser considerados para o sucesso desta fase relacionam-se às condições fisiológicas das plantas matrizes, o processo de assepsia e a manipulação dos explantes.

\section{(1) Seleção dos explantes}

Diversos tipos de explantes podem ser utilizados para iniciar a propagação in vitro. $\mathrm{Na}$ seleção dos explantes, devem ser considerados aspectos como o nível de diferenciação do tecido utilizado e a finalidade da micropropagação (Wendling et al., 2006). De modo geral, a micropropagação de espécies lenhosas é mais restritiva devido ao elevado nível de diferenciação dos tecidos, comparativamente às espécies herbáceas (Villa et al., 2009). Assim, a seleção dos explantes deve ser realizada, preferencialmente, a partir de brotações fisiologicamente ativas em estádio primário de crescimento.
Os explantes coletados a partir de árvores adultas devem possuir características juvenis. Para tanto, empregam-se técnicas de indução de rejuvenescimento da matriz doadora. A decepa das árvores adultas é o principal procedimento recomendado para obtenção de brotações com características juvenis. No entanto, o procedimento é recomendado apenas para aquelas espécies que apresentam a capacidade de rebrota a partir da cepa. Quando a decepa da árvore adulta não é possível , o anelamento parcial na base do tronco é uma alternativa indicada para obtenção de explantes (Alfenas et al., 2009). Outra alternativa refere-se ao resgate de material vegetativo a partir de galhos podados da copa da árvore e acondicionados em casa de vegetação (Almeida et al., 2007; Wendling et al., 2013). As brotações epicórmicas induzidas nos galhos das árvores são utilizadas como explantes para a introdução in vitro.

$\mathrm{O}$ estado fisiológico da planta-matriz tem grande influência na morfogênese, no crescimento e nas taxas de multiplicação in vitro, o que pode ser melhorado com adequado pré-tratamento ambiental das plantasmatrizes, particularmente quanto à nutrição e ao controle fitossanitário (Borges et al., 2011). Os prétratamentos aplicados na planta matriz são determinantes para o sucesso da desinfestação e estabelecimento in vitro dos explantes, principalmente no que se refere a microorganismos endógenos. Os tratamentos fitossanitários nas plantas matrizes têm por objetivo manter os agentes microbianos internos (endofíticos) nos níveis mais baixos possíveis, enquanto os externos devem ser totalmente eliminados. Em geral, soluções antimicrobianas de ação sistêmica e de contato são pulverizadas nas plantas para o controle de agentes microbianos internos e externos, respectivamente (Wendling et al., 2006). O cultivo e a manutenção das matrizes fornecedoras dos explantes devem ser realizados nas melhores condições de sanidade e fertilidade, sendo recomendado que sejam feitas em condições controladas para que possam receber tratamento fitossanitário e nutrição mineral adequada (Teixeira, 2001), como o cultivo em vaso ou em minijardins clonais em sistemas semi-hidropônicos.

No estabelecimento in vitro de Aspidosperma polyneuron as mudas, utilizadas como fonte de explantes, foram mantidas em casa de vegetação e previamente pulverizadas com 0,5 g. $\mathrm{L}^{-1}$ de benomyl (fungicida sistêmico benlate-500) (Ribas et al., 2005). 
Em Cordia trichotoma o controle fitossanitário e nutricional foi feito por meio de pulverizações semanais de solução contendo fungicidas sistêmicos e de contato $\mathrm{e}$, quinzenalmente, mediante regas com solução nutritiva (Mantovani et al., 2001). A manutenção das mudas de Ocotea porosa na casa de vegetação como pré tratamento para o estabelecimento in vitro contribuiu para haver baixos níveis de contaminação dos explantes no cultivo in vitro (Pelegrini et al., 2011).

A micropropagação das espécies florestais brasileiras tem sido realizada basicamente utilizando-se propágulos provenientes de sementes germinadas in vitro, dada a dificuldade em se obter material de plantas adultas, livre de microrganismos e de serem responsivas à propagação em condições controladas, conforme relatado em diversos trabalhos (Tabela 1). Devido às dificuldades apresentadas na propagação in vitro de material adulto há poucos trabalhos que reportam a utilização de segmentos nodais coletados a partir de árvores maduras estabelecidas a campo, a exemplo dos trabalhos reportados com $C$. trichotoma (Mantovani et al., 2001) e Eugenia involucrata (Golle et al., 2012).

Os ápices e gemas laterais isolados de plântulas germinadas in vitro são os principais tipos de explantes utilizados na micropropagação das espécies florestais. Hubner et al. (2007) e Santos et al. (2006) utilizaram segmentos apicais de material juvenil germinado in vitro para multiplicar Aspidosperma ramiflorum e Caryocar brasiliense, respectivamente. Flôres et al. (2011) e Léon (2010) concluíram que tanto ápices caulinares quanto segmentos nodais podem ser empregados para o estabelecimento in vitro de Luehea divaricata, assemelhando-se ao resultado encontrado por Bassan et al. (2006) no estabelecimento in vitro de Peltophorum dubium. Em outro estudo, Nascimento (2008) observou que o segmento cotiledonar foi o melhor tipo de explante para regeneração in vitro de Parapiptadenia rigida ao comparar com o segmento nodal. Curti (2011) concluiu que o uso de epicótilo contendo o nó cotiledonar eleva em 75\% a emissão de brotações axilares de Peltophorum dubium em comparação à utilização do epicótilo isoladamente. Da mesma forma, Costa et al. (2010) obtiveram sucesso na propagação in vitro de Erythrina velutina utilizando segmento nodal e o nó cotiledonar como explantes.

Segundo Wendling et al. (2006), as gemas apicais tendem a apresentar maior capacidade de crescimento que gemas axilares, devido ao forte efeito da dominância apical. Geralmente, devido ao pequeno número de gemas apicais disponíveis em espécies arbóreas ou à sua maior sensibilidade à desinfestação, utilizam-se gemas axilares ou outros tipos de meristemas, como os oriundos das flores e folhas. Ferreira et al. (2009) utilizaram explantes florais para introdução in vitro de Theobroma grandiflorum, obtendo sucesso a partir dessa metodologia.

Os embriões ou tecidos de sementes são também utilizados como explantes iniciais na micropropagação. Reis et al. (2009) utilizaram eixos embrionários na micropropagação de Schizolobium amazonicum. A utilização deste tipo de explante apresenta vantagens do ponto de vista experimental para a determinação de um protocolo de micropropagação (Wendling et al., 2006). Entretanto, como o embrião é resultado de recombinação gênica, constituindo um novo genótipo, este fato acaba limitando o processo de clonagem de indivíduos superiores estabelecidos a campo.

\section{(2) Desinfestação dos explantes}

As plantas lenhosas apresentam dificuldades para o estabelecimento in vitro, principalmente devido à contaminação por microrganismos (Erig \& Schuch, 2003). Os plantios com espécies nativas ainda ocupam reduzidas áreas, representando um problema para coleta e seleção de explantes para o estabelecimento in vitro. $\mathrm{O}$ controle fitossanitário da planta doadora de propágulos torna-se difícil em situações em que as plantas matrizes encontram-se em áreas de floresta.

A assepsia dos explantes não expõe os microrganismos endógenos aos agentes desinfestantes. Portanto, sugerese iniciar o controle asséptico com a aplicação de tratamentos na planta-matriz previamente à coleta de propágulos, o qual caracteriza-se por um procedimento árduo e dispendioso quando a planta encontra-se estabelecida a campo (Xavier et al., 2013). Apesar da maioria dos microrganismos não serem patogênicos, o seu crescimento é acelerado no meio de cultura a tal ponto que competem com os explantes por nutrientes, prejudicando o desenvolvimento e crescimento dos mesmos (Yamazaki et al., 1995).

De acordo com Cid \& Zimmermann (2006), o uso de meristemas, de compostos químicos e de plantas germinadas in vitro são as alternativas para contornar a contaminação. Mesmo assim, por muitas vezes, não é possível trabalhar com meristemas ou ainda obter explantes em condições assépticas. Dessa forma, várias substâncias com ação germicida são utilizadas 
visando a desinfestação dos explantes. Dentre os agentes desinfestantes mais frequentemente utilizados para a assepsia de sementes visando a propagação in vitro, destaca-se o hipoclorito de sódio. Este composto apresentou resultados satisfatórios para a desinfestação de sementes de Swietenia macrophylla (Couto et al., 2004), Cedrela fissilis (Amaral, 2006), C. trichotoma (Fick et al., 2007; Heberle, 2010), Parapiptadenia rigida (Nascimento, 2008) e Moringa oleifera (Cysne, 2006). Outros agentes desinfestantes utilizados são: ácido clorídrico, cloreto de benzalcônico, peróxido de hidrogênio, nitrato de prata, formaldeído e óxido de etileno (Wendling et al., 2006).

As combinações dos princípios ativos desinfestantes podem variar muito (Montarroyos, 2000), sendo necessária adequação de acordo com a espécie e a sensibilidade do tecido a ser desinfestado (Erig \& Schuch, 2003). Além disso, a imersão em água quente pode controlar parcialmente os microrganismos associados às sementes, conforme relatado por Flôres et al. (2011) ao desinfestar sementes de Luehea divaricata.

$\mathrm{O}$ uso de antibióticos e fungicidas em meio de cultura justifica-se quando há contaminação microbiana proveniente de infecções sistêmicas das plantas matrizes (Wendling et al., 2006). Além dos antibióticos e fungicidas, o uso de antioxidantes é justificável em espécies lenhosas cujo estabelecimento e crescimento in vitro são dificultados ou limitados pela liberação de exsudados derivados da oxidação de compostos fenólicos.

As concentrações das soluções desinfestantes, assim como as combinações dos princípios ativos e os tempos de exposição, podem variar consideravelmente. Algumas gotas de detergente são comumente adicionadas às soluções a base de cloro para melhorar o contato destas com os tecidos, a partir da redução da tensão superficial da água, facilitando a ação do tratamento asséptico. Também podem ser utilizados fungicidas e bactericidas durante a desinfestação com a incorporação em baixas concentrações ao meio de cultura de isolamento (Teixeira, 2001). Sato et al. (2001) observaram que o fungicida Benlate ${ }^{\circledR}\left(200 \mathrm{mg} \mathrm{L}^{-1}\right)$ foi eficiente para controlar a contaminação fúngica em explantes de Celtis sp. Ferreira et al. (2009) concluíram que a ação do antibiótico cefotaxima (100 $\left.\mathrm{mg} \mathrm{L}^{-1}\right)$ juntamente com o hipoclorito de sódio controlou a contaminação de explantes florais de Theobroma grandiflorum. A contaminação bacteriana de segmentos nodais de Cedrela fissilis foi controlada pela inclusão ao meio de cultura de estreptomicina e Benlate ${ }^{\circledR}$, na concentração de 10 $\mathrm{mg} \mathrm{L}^{-1}$ e $300 \mathrm{mg} \mathrm{L}^{-1}$, respectivamente (Amaral, 2006).

\section{(3) Manipulação dos explantes}

A oxidação dos explantes é outro obstáculo a ser superado durante o estabelecimento in vitro de espécies lenhosas (Silva et al., 2007). A oxidação fenólica é altamente dependente do genótipo, da fase de desenvolvimento da planta e da estação do ano (Werner et al., 2009). Os tecidos recém excisados, principalmente das angiospermas, tendem a secretar em elevadas proporções substâncias fenólicas e taninos no meio de cultura, em resposta ao ferimento sofrido, os quais podem modificar a composição do meio de cultivo e a absorção de metabólitos (Andrade et al., 2000), prejudicando o cultivo in vitro.

Dentre as alternativas para a redução deste problema recomenda-se a lavagem dos explantes em água corrente previamente à desinfestação, auxiliando na lixiviação dos compostos fenólicos (Grattapaglia \& Machado, 1998). Em geral, adiciona-se aos meios de cultura substâncias antioxidantes, como ácido cítrico, ácido ascórbico, polivinilpirrolidone (PVP) e carvão ativado (Werner et al., 2009). A atividade das enzimas no que diz respeito à biossíntese e oxidação de fenóis são aumentadas pela luz, portanto, o escurecimento dos tecidos poderá ser reduzido e até mesmo impedido, caso os explantes sejam incubados no escuro (Melo et al., 2001). A oxidação fenólica tem sido controlada em diferentes espécies lenhosas pela redução da concentração de sais e de reguladores de crescimento no meio de cultura e notadamente pela adição de antioxidantes ao meio (Bassan et al., 2006). Além disso, recomenda-se o subcultivo dos explantes para novo meio de cultura em menor espaço de tempo.

\section{Multiplicação e alongamento}

Nesta fase, o principal objetivo é produzir o maior número de gemas ou brotos possíveis, no menor intervalo de tempo e com o mínimo de variação genética entre explantes, além de livres de contaminantes que prejudiquem a micropropagação (Léon, 2010). A qualidade e homogeneidade das partes aéreas produzidas também são importantes, pois influenciam o enraizamento adventício posterior, tanto in vitro quanto ex vitro.

Alguns fatores afetam o desenvolvimento das culturas durante a fase de multiplicação, como a frequencia de subcultivos, o tipo e tamanho dos explantes subcultivados 
e os cuidados no procedimento da repicagem (Correia et al., 1995). Um dos principais desafios baseia-se em estabelecer as melhores combinações e os tipos de reguladores de crescimento que proporcionem o crescimento e desenvolvimento adequados dos explantes de espécies lenhosas. Dependendo dos objetivos da micropropagação, deve-se atentar para o tempo e número de subcultivos necessários durante a multiplicação, até alcançar estádios vegetativos com reatividade das gemas, de acordo com os interesses da propagação (Xavier \& Otoni, 2009).

A resposta a maior ou menor taxa de multiplicação ou alongamento, normalmente, tem sido estabelecida pelo balanço hormonal dos reguladores de crescimento. O 6-benzilaminopurina (BAP) corresponde à citocinina mais utilizada nos trabalhos de micropropagação de espécies florestais, sendo empregada isoladamente na multiplicação in vitro de Schizolobium amazonicum (Cordeiro et al., 2004a), Cabralea canjerana (Rocha et al., 2007), Luehea divaricata (Flôres et al., 2011), Ocotea porosa (Pelegrini et al., 2011), Ocotea odorifera (Moritz et al., 2009), Cordia trichotoma (Heberle, 2010) e Erythrina velutina (Costa et al., 2010). O BAP também foi utilizado combinado com outras citocininas, como a zeatina (ZEA) e a cinetina (KIN) na micropropagação de Aspidosperma polyneurum (Ribas et al., 2005) e com a isopenteniladenina (2-iP) na propagação in vitro de Swietenia macrophylla (Schottz et al., 2007). Além disso, faz-se o uso da ação combinada de BAP com o ácido naftalenoacético (ANA) (uma auxina sintética), como por exemplo na micropropagação de Cedrella fissilis (Amaral, 2006), Caryocar brasiliense (Santos et al., 2006), Aspidosperma ramiflorum (Hubner et al., 2007) e Maclura tinctoria (Gomes et al., 2010).

Os meios de cultura constituem também um fator relevante na micropropagação, uma vez que possuem substâncias essenciais para o crescimento dos tecidos, controlam o padrão de desenvolvimento e a resposta morfogênica in vitro (Caldas et al., 1998), influenciando as respostas morfofisiológicas dos explantes (Almeida et al., 2012). Existe uma grande variedade de meios de cultura adaptados para diversas espécies, diferindo, sobretudo quanto à constituição e concentração de nutrientes (Amaral, 2006). Entretanto, o meio de cultura MS (Murashige \& Skoog, 1962) corresponde a um dos mais utilizados na propagação de espécies florestais nativas, como por exemplo, ao reportado para
Peltophorum dubium (Bassan et al., 2006), Cedrela fissilis (Amaral, 2006), Cabralea canjerana (Rocha et al., 2007), Hancornia speciosa (Lédo et al., 2007), Ocotea porosa (Pelegrini et al., 2011) e Schizolobium parayba var. amazonicum (Reis et al., 2009). Além do meio de cultura MS, o meio WPM (woody plant medium) (Lloyd \& McCown, 1981), desenvolvido especialmente para o cultivo in vitro de espécies lenhosas, também é utilizado para muitas espécies florestais. Flôres et al. (2011) concluíram que o meio WPM foi o mais eficiente para a micropropagação de Luehea divaricata, bem como Fick et al. (2007) para a propagação in vitro de Cordia trichotoma.

A inclusão de substâncias adsorventes ao meio de cultura tem sido relatada como uma condição indispensável para o cultivo in vitro de espécies lenhosas (Werner et al., 2009; Moritz et al., 2009). São relatados também resultados positivos com a adição de ácido cítrico e ácido ascórbico ao meio de cultura, visando controlar a oxidação para Schizolobium amazonicum (Cordeiro et al., 2004b), e com o acréscimo de carvão ativado ao meio de cultura durante a multiplicação de gemas de Cordia trichotoma (Heberle, 2010).

O cultivo in vitro das espécies florestais por meio da utilização de biorreatores é uma alternativa mais eficiente para a produção de mudas em larga escala com custos reduzidos, semelhante ao desenvolvido para cana-de-açúcar (Mordocco et al., 2009) e banana (Kosky et al., 2006). Embora os sistemas de biorreatores apresentem vantagens em comparação com a micropropagação convencional para algumas espécies vegetais agronômicas, como abacaxi (Escalona et al., 1999; Silva et al., 2007), banana (Lemos et al., 2001), batata (Teisson \& Alvard, 1999), cana-de-açúcar (Lorenzo et al., 1998), essa técnica de propagação ainda não tem sido empregada em grande escala para espécies florestais nativas, tendo sido relatada até o presente momento apenas para Jacaranda decurrens (Malosso et al., 2012). Neste trabalho, a taxa de multiplicação dos explantes cultivados no sistema de imersão temporária RITA $^{\circledR}$ foi superior à obtida em meio de cultura semisólido. Esses resultados indicam que os biorreatores constituem sistemas promissores para a multiplicação em larga escala de espécies florestais nativas, consolidando um campo promissor para o desenvolvimento de futuros trabalhos. 


\section{Enraizamento e aclimatização}

$\mathrm{O}$ enraizamento in vitro caracteriza-se pela indução de raízes adventícias em brotações alongadas, a partir de gemas na fase de multiplicação/alongamento, visando à obtenção de plantas completas para posterior transplante e aclimatização para as condições ex vitro. De modo geral, os materiais genéticos de espécies lenhosas em idade ontogenética mais avançada apresentam maiores dificuldades para o enraizamento adventício (Mantovani et al., 2010; Almeida et al., 2007). O enraizamento pode ser induzido tanto in vitro quanto ex vitro. No caso de enraizamento in vitro, as raízes são induzidas em meio de cultura sob condições laboratoriais, sendo em última fase, as plantas transplantadas para substratos e acondicionadas em casa de vegetação para a aclimatização. Neste caso, tem-se melhor controle das condições de cultura obtendo-se elevados percentuais de enraizamento (Leitzke et al., 2009).

Em geral, a composição do meio de cultura e o tipo e concentrações de auxina são as variáveis que mais influenciam o enraizamento, sendo as respostas dependentes do material genético. Curti (2011) não obteve sucesso em induzir raízes in vitro em brotações de Peltophorum dubium na presença das auxinas ANA, ácido indolbutírico (AIB) e ácido 2,4-diclorofenoxiacético (2,4-D). De acordo com Fett Neto et al. (1992), em espécies florestais lenhosas, o enraizamento adventício é induzido em meio de cultura com auxina, com a posterior transferência para meio de cultura isento de regulador de crescimento, estimulando, assim, a rizogênese e o crescimento das raízes. Dentre as auxinas, o ácido indolbutírico (AIB) tem sido muito utilizado em razão da baixa fitotoxicidade aos explantes, proporcionando resultados positivos ao enraizamento in vitro, como o reportado para Caryocar brasiliense (Santos et al., 2006), Ocotea porosa (Pelegrini et al., 2011) e Parapiptadenia rigida (Kielse, 2009). A adição de outros componentes ao meio de cultura também pode favorecer o enraizamento, como o ácido giberélico $\left(\mathrm{GA}_{3}\right)$ na micropropagação de Cedrela fissilis (Amaral, 2006) e de carvão ativado no enraizamento de Maclura tinctoria (Gomes et al., 2010).

Em relação ao enraizamento ex vitro, as brotações alongadas são enraizadas diretamente em substrato. A opção por um dos sistemas depende da qualidade das partes aéreas obtidas na multiplicação da espécie, do genótipo e da infra-estrutura adequada (Santos et al., 2004). De acordo com Wendling et al. (2006) o enraizamento ex vitro é mais eficiente, proporcionando a indução de sistema radicial mais adequado do ponto de vista morfogênico, além de ser mais prático e econômico ao se comparar com o enraizamento in vitro.

A auxina AIB tem sido utilizada com frequência para a indução do enraizamento ex vitro. Ribas et al. (2005) obtiveram sucesso no enraizamento de Aspidosperma polyneuron com a imersão das bases das microestacas em solução de AIB. Da mesma forma, Rocha et al. (2007) enraizaram microestacas de Cabralea canjerana, utilizando AIB.

A aclimatização é um dos processos indispensáveis para a obtenção de uma microplanta completa (Wendling et al., 2006). A transferência de brotações ou microplantas das condições assépticas e heterotróficas, típicas na cultura de tecidos, para o crescimento em ambiente externo deve ser realizada gradativa e cuidadosamente. Isso se deve aos explantes apresentarem elevado conteúdo de água condições in vitro (Kubota \& Kozai, 1992) ou com desordens anatômicas e fisiológicas que não possibilitam que o aparato fotossintético opere normalmente (Arigita et al., 2002). A alta umidade do ar nos frascos de cultura altera a estrutura da cutícula, os depósitos de cera, e as células do mesófilo e dos estômatos das folhas, tornando as plantas suscetíveis a grandes perdas de água por transpiração (Costa et al., 2008). Portanto, o sucesso da aclimatização é dependente do controle de fatores, como temperatura, luminosidade, umidade, substrato e nutrientes.

O processo de aclimatização é realizado com incremento da irradiância, mantendo-se elevada umidade relativa do ambiente após o transplantio, seguido de redução da mesma, até que a fase de rustificação se complete (Campostrini \& Otoni, 1996). Geralmente, a umidade relativa do ar (UR), em particular no início do processo, é controlada em casa de vegetação a partir da utilização de estrutura coberta com filme plástico (polietileno) e com nebulização frequente em intervalos pré-determinados. Rocha et al. (2007) observaram 90\% de sobrevivência em microestacas de Cabralea canjerana ao aclimatizá-las em casa de vegetação durante 30 dias. $\mathrm{O}$ uso de uma estrutura coberta com sombrite também favorece a aclimatização, conforme relatado por Gomes et al. (2010) com plantas micropropagadas de Maclura tinctoria, reportando 97\% de sobrevivência.

O substrato é outro fator importante envolvido na aclimatização ex vitro, pois ele pode facilitar ou impedir o crescimento das plantas (Skrebsky et al., 2006). As características do substrato como o elevado espaço de aeração associado à elevada capacidade de retenção de 
água são fatores fundamentais durante a aclimatização (Girardi \& Pescador, 2010). Diversos substratos tem sido utilizados, tais como substratos comerciais para o plantio de hortaliças, fibras de coco, vermiculita ou areia. No entanto, embora o substrato possa ser formado por um único material, dificilmente será encontrado um ideal com todas as características necessárias, sendo utilizada a mistura de dois ou mais materiais.

\section{Organogênese e embriogênese somática}

De acordo com Xavier et al. (2013), a organogênese corresponde à indução de gemas adventícias diretamente sobre o explante ou calo (ou seja, organogênese indireta), mediante a desdiferenciação e rediferenciação celular, levando à formação de uma planta completa a partir da atividade meristemática em células maduras diferenciadas. Xavier \& Otoni (2009) relataram que o processo de organogênese in vitro é considerado complexo, com a atuação de múltiplos fatores externos e internos, envolvendo interação entre fonte de explante, meio de cultura, fatores do ambiente, ação de reguladores de crescimento, em particular auxinas e citocininas, como também da habilidade dos tecidos em responder a mudanças hormonais durante o período de cultivo.

$\mathrm{Na}$ área florestal, este sistema de micropropagação tem potencialidade de utilização na conservação de germoplasma in vitro, aplicação nos programas de propagação clonal, auxiliando no desenvolvimento de protocolos eficientes de regeneração para diversas espécies, no melhoramento florestal, como também, na obtenção de plantas transgênicas via transformação genética (Xavier et al., 2013). No entanto, diante da escassez de informações referentes à organogênese in vitro de espécies florestais nativas, ainda se faz necessária a adequação de protocolos de regeneração visando aplicação na propagação in vitro. Dentre os trabalhos publicados via organogênese destacam-se os desenvolvidos para Hancornia speciosa (Soares et al., 2007) e Miconia sp. (Cid et al., 1997).

A embriogênese somática, embora tenha um enorme potencial de aplicação na área florestal, ainda apresenta poucas pesquisas que envolvam espécies florestais nativas, demonstrando uma carência de estudos com esta técnica. Alguns trabalhos tem sido desenvolvidos com Araucaria angustifolia (Astarita \& Guerra, 2000; Santos et al., 2002; Silveira et al., 2002), Hevea brasiliensis (Sobha et al., 2003), Acca sellowiana (Booz
\& Pescador, 2007), Caesalpinia echinata (Werner et al., 2007), Myrciaria aureana (Motoike et al., 2007), Acrocomia aculeata (Moura et al., 2008), Theobroma cacao (Silva et al., 2009) e Amburana acreana (Fermino Junior \& Pereira, 2012), demonstrando que essa técnica é promissora para a propagação in vitro de espécies nativas, considerando que a sua aplicabilidade deverá ser melhor investigada em futuros trabalhos.

\section{Considerações finais}

Amicropropagação de espéciesflorestais nativas apresentase com potencial para a conservação de germoplasma in vitro, limpeza clonal, produção massiva de mudas de espécies, aceleração de programas de melhoramento pela multiplicação de clones, além de atuar como base para outras técnicas biotecnológicas, como a transformação genética e a produção de metabólitos secundários.

Entretanto, em vista do grande número de espécies florestais, há carência de trabalhos de propagação in vitro, os quais têm sido realizados principalmente para o desenvolvimento de protocolos de micropropagação, com pesquisas relacionadas aos meios de cultura, componentes dos meios nutritivos, concentrações de reguladores de crescimento, seleção e desinfestação de explantes. Ainda residem dificuldades relacionadas à micropropagação, como contaminações fúngicas e bacterianas endofíticas, oxidação fenólica e ausência de resposta morfogênica dos explantes.

Diante do exposto, a micropropagação não deve ser visualizada isoladamente, mas sim, como uma ferramenta de complementação das demais técnicas convencionais de propagação seminal e demais sistemas, como biorreatores.

\section{Referências}

ALFENAS, A. C.; ZAUZA, E. A. V.; MAFIA, R. G.; ASSIS, T. F. Clonagem e doenças do eucalipto. 2. ed. Viçosa, MG: Ed da UFV, 2009. 500 p.

ALMEIDA, F. D.; XAVIER, A.; DIAS, J. M. M.; PAIVA, H. N. Eficiência das auxinas (AIB e ANA) no enraizamento de miniestacas de clones de Eucalyptus cloeziana F. Muell. Revista Árvore, Viçosa, MG, v. 31, n. 3, p. 455-463, 2007.

ALMEIDA, M.; ALMEIDA, C. V.; GRANER, E. M.; BRONDANI, G. E.; ABREU-TARAZI, M. F. Pre-procambial cells are niches for pluripotent and totipotent stem-like cells for organogenesis and somatic embryogenesis in the peach palm: a histological study. Plant Cell Reports, New York, v. 31, n. 8, p. 1495-1515, 2012. 
AMARAL, V. F. M. Multiplicação in vitro de Cedrella fissilis Vell. 2006. 79 f. Dissertação (Mestrado em Engenharia Florestal) Universidade Federal de Santa Maria, Santa Maria, RS.

ANDRADE, M. W.; LUZ, J. M. Q.; LACERDA, A. S.; MELO, P. R. A. Micropropagação da aroeira (Myracrodruon urundeuva Fr. All). Ciência Agrotécnica, Lavras, v. 24, n. 1, p. 174-180, 2000.

ARIGITA, L.; GONÇÁLEZ, A.; TAMÉS, R. S. Influence of $\mathrm{CO}_{2}$ and sucrose on photosynthesis and transpiration of Actinidia deliciosa explants cultured in vitro. Physiologia Plantarum, Copenhagen, v. 115, p. 166-173, 2002.

ASTARITA, L. V.; GUERRA, M. P. Conditioning of the culture medium by suspension cells and formation of somatic proembryo in Araucaria angustifolia (Coniferae). In Vitro Cellular Development and Biology Plant, Wallingford, v. 36, n. 3, p. 194-200, 2000.

BASSAN, J. S.; REINIGER, L. R. S.; ROCHA, B. H. G.; SEVERO, C. R. P.; FLÔRES, A. V. Oxidação fenólica, tipo de explante e meios de cultura no estabelecimento in vitro de canafístula (Peltophorum dubium (SPRENG.) TAUB.). Ciência Florestal, Santa Maria, RS, v. 16, n. 4, p. 381-390, 2006.

BOOZ, M. R.; PESCADOR, R. Efeito do Ácido $\gamma$-aminobutírico (Gaba) na Embriogênese Somática de Acca sellowiana (Myrtaceae). Revista Brasileira de Biociências, Porto Alegre, v. 5, n. 2, p. 198-200, 2007.

BORGES, S. R.; XAVIER, A.; OLIVEIRA, L. S.; MELO, L. A.; ROSADO, M. A. Enraizamento de miniestacas de clones híbridos de Eucalyptus globulus. Revista Árvore, Viçosa, MG, v. 35, n. 3, p. 425-434, 2011.

BRUnetTA, J. M. F. C.; OtONi, W. C.; PInheiro, A. L.; FONSECA, É. P. Calogênese in vitro em segmentos de epicótilo de mogno (Swietenia macrophylla King) com o uso de 6-benzilaminopurina e ácido $\alpha$-naftalenoacético. Scientia Forestalis, Piracicaba, n. 71, p. 19-24, 2006.

CALDAS, L. S.; HARIDASAN, P.; FERREIRA, M. E. Meios nutritivos. In: TORRES, A. C., CALDAS, L. S. Técnicas e aplicações da cultura de tecidos de plantas. Brasília, DF: ABCTP; EMBRAPA-CNPH, 1990. p. 37-70.

CAMPOSTRINI, E.; OTONI, W. C. Aclimatação de mudas: abordagens recentes. ABCTP Noticias, Brasília, DF, n. 25, p. 2-12, 1996.

CID, L. P. B.; GOMES, A. C. M.; COSTA S. B. R.; TEIXEIRA, J. B. Micropropagation of Miconia sp., a woody Melastomataceae from Brazil, using thidiazuron as plant growth regulator. Revista Brasileira Fisiologia Vegetal, Campinas, v. 9, n. 1, p. 21-25, 1997.

CID L. P. B.; ZIMMERMANN M. J. A contaminação in vitro de plantas. Brasília, DF: Embrapa Recursos Genéticos e Biotecnologia, 2006. 20 p. (Embrapa Recursos Genéticos e Biotecnologia. Boletim de Pesquisa e Desenvolvimento, 122).

CORDEIRO, I. M. C. C.; LAMEIRA, O. A.; OHASHI, S. T.; ROSAL, L. F. Efeito de BAP sobre a proliferação de brotos in vitro de Schizolobium amazonicum Huber ex Ducke. Cerne, Lavras, v. 10, n. 1, p. 118-124, 2004a.

CORDEIRO, I. M. C. C.; LAMEIRA, O. A.; MENEZES, I. C.; COSTA, M. P.; REIS, L. R. S. Efeito de diferentes concentrações de nitrato de amônio no controle da oxidação in vitro em segmento caulinar de paricá (Schizolobium amazonicum) Huber ex (Ducke). Revista Ciência Agrária, Belém, n. 41, p. 97-104, 2004 b.
CORREIA, D.; CONÇALVES, A. N.; COUTO, H. T. Z.; RIBEIRO, M. C. Efeito do meio de cultura líquido e sólido no crescimento e desenvolvimento de gemas de Eucalyptus grandis $x$ Eucalyptus urophylla na multiplicação in vitro. IPEF, Piracicaba, v. 48, p. 107-116, 1995.

COSTA, F. H. S.; PEREIRA, J. E. S.; PASQUAL, M.; CASTRO, E. M.; SANTOS, A. M. Perda de água e modificações anatômicas em folhas de plantas de bananeiras micropropagadas durante a aclimatização. Ciência. Rural, Santa Maria, RS, v. 39, n. 3, p. 742-748, 2008.

COSTA, G. M.; NePOMUCENO, C. F.; SANTANA, J. R. F. Propagação in vitro de Erythrina velutina. Ciência Rural, Santa Maria, RS, v. 40, n. 5, p. 1090-1096, 2010.

COUTO, J. M. F.; OTONI, W. C.; PINHEIRO, A. L.; FONSECA, E. P. Desinfestação e germinação in vitro de sementes de mogno (Swietenia macrophylla King). Revista Árvore, Viçosa, MG, v. 28, n. 5, p. 633-642, 2004.

CURTI, A. R. Contribuições para a micropropagação de Peltophorum dubium (SPRENGEL) Taubert. 2011. $96 \mathrm{f}$. Dissertação (Mestrado em Engenharia Florestal) - Universidade Federal de Santa Maria, Santa Maria, RS.

CYSNE, J. R. B. Propagação in vitro de Moringa oleifera L. 2006. 81 f. Dissertação (Mestrado em Fitotecnia) - Universidade Federal do Ceará, Fortaleza.

DEBNATH, S. C. Clonal propagation of dwarf raspberry (Rubus pubescens Raf.) through in vitro axillary shoot proliferation. Plant Growth Regulation. Boston, n. 4, v. 3, p. 179-186, 2004.

DESCHAMPS, C.; PINTO, J. E. B. P. Enraizamento in vitro de microestacas e micropropagação de gemas axilares de sarandi (Sebastiania schottiana Muell. arg.). Ciência Rural, Santa Maria, RS, v. 25, n. 3, p. 389-393, 1995.

DIAS, P. C.; OLIVEIRA, L. S.; XAVIER, A.; WENDLING, I. Estaquia e miniestaquia de espécies florestais lenhosas do Brasil. Pesquisa Florestal Brasileira, Colombo, v. 32, p. 72, p. 453-462, 2012. DOI: http://dx.doi.org/10.4336/2012.pfb.32.72.453

DUTRA, L. F.; WENDLING, I.; BRONDANI, G. E. A micropropagação de eucalipto. Pesquisa Florestal Brasileira, Colombo, n. 58, p. 49-59, 2009. DOI: 10.4336/2009.pfb.58.49

ERIG, A. C.; SCHUCH, M. W. Tipo de explante e controle da contaminação e oxidação no estabelecimento in vitro de plantas de macieira (Malus domestica Borkh.) cvs. Galaxy, Maxigala e Mastergala. Revista Brasileira Agrociência, Pelotas, v. 9, n. 3, p. 221-227, 2003.

ESCALONA, M.; LORENZO, J. C.; GONZÁLEZ, B.; DAQUINTA, M.; GONZÁlEZ, J. L.; DESJARDINS, Y.; BORROTO, C. G. Pineapple (Ananas comosus L. Merr) micropropagation in temporary immersion systems. Plant Cell Reports, New York, v. 18, p. 743748, 1999.

FEARNSIDE, P. M. Plantation forestry in Brazil: projections to 2050. Biomass and Bioenergy, Kidlington, v. 15, n. 6, p. 437-450, 1998.

FERMINO JUNIOR, P. C. P.; NAGAO, E. O.; PEREIRA, J. E. S. Estabelecimento, germinação e multiplicação in vitro de teca (Tectona grandis L.f.) a partir de genótipos da Amazônia Sul-Ocidental. Scientia Forestales, Piracicaba, v. 37, n. 84, p.4 27-435, 2009. 
FERMINO JUNIOR, P. C. P.; PEREIRA, J. E. S. Germinação e propagação in vitro de cerejeira (Amburana acreana (Ducke) A.C. Smith - Fabaceae). Ciência Florestal, Santa Maria, RS, v. 22, n. 1, p. 1-9, 2012.

FERRARI, M. P.; GROSSI, F.; WENDLING, I. Propagação vegetativa de espécies florestais. Colombo: Embrapa Floresta, 2004. 22 p. (Embrapa Florestas. Documentos, 94).

FERREIRA, M. das G. R.; SANTOS, M. R. A.; BRAGADO, A. C. $R$. Propagação in vitro de cupuaçuzeiro: desinfestação de explantes florais. Saber Científico, Porto Velho, v. 2, n. 2, p. 37-44, 2009.

FETT-NETO, A. G.; TEIXEIRA, S.; SILVA, E. A. M.; SANTANNA, $\mathrm{R}$. Biochemical and morphological changes during in vitro rhizogenes in cuttings of Sequoia sempervirens (D. Don) Endl. Journal of Plant Physiology, Stuttgart, v. 140, p. 720-728, 1992.

FICK, T. A.; BISOGNIN, D. A.; QUADROS, K. M.; HORBACH, M.; REINIGER, L. R. Estabelecimento e crescimento in vitro de plântulas de louro-pardo (Cordia trichotoma). Ciência Florestal, Santa Maria, RS, v. 17, n. 4, p. 343-349, 2007.

FLÔRES, A. V. REINIGER, L. R. S.; CURTI, A. R.; CUNHA, A. C. M. C. M.; GOLLE, D. P.; BASSAN, J. S. Estabelecimento e multiplicação in vitro de Luehea divaricata Mart. \& Zucc. Ciência Florestal, Santa Maria, RS, v. 21, n. 1, p. 175-182, 2011a.

FLÔRES, A. V.; REINIGER, L. R. S.; CURTI, A. R.; PAIM, A.; BASSAN, J. S.; CUNHA, A. C. M. C. M. Estabelecimento in vitro de Peltophorum dubium ((Spreng.) Taub.) em função das concentrações do meio MS. Cerne, Lavras, v. 17, n. 4, p. 549-553, 2011 b.

FRANÇA, S. C.; DUARTE, I. B.; MORAES, R. M.; PEREIRA, A. M. S. Micropropagation og Stryphnodendron polyphythum (barbatimão). Plant Cell, Tissue and Organ Culture, Dordrecht, v. 42, p. 291-293, 1995.

FRANCO, E. T. H.; GAVIOLLI, B.; FERREIRA, A. G. In vitro regeneration of Didymopanax morototoni. Brazilian Journal Biology, Rio de Janeiro, v. 66, n. 2, p. 455-462, 2006.

FUMAGAli, E.; GONÇALVES, R. A. C.; MACHADO, M. F. P. S.; VIDOTI, G. J.; OLIVEIRA, A. J. B. Produção de metabólitos secundários em cultura de células e tecidos de plantas: o exemplo dos gêneros Tabernaemontana e Aspidosperma. Revista Brasileira de Farmacognosia, João Pessoa, v. 18, n. 4, p. 627-641, 2008.

GIRARDI, C. G.; PESCADOR, R. Aclimatação de gengibre (Zingiber officinale Roscoe) e a relação com carboidratos endógenos. Revista Brasileira Plantas Medicinais, Botucatu, v. 12, n. 1, p. 62-72, 2010.

GOLLE, D. P.; REINIGER, L. R. S.; CURTI, A. R.; LEÓN, E. A. B. Estabelecimento e desenvolvimento in vitro de Eugenia involucrata DC.: influência do tipo de explante e do meio nutritivo. Ciência Florestal, Santa Maria, RS, v. 22, n. 1, p. 207-214, 2012.

GOMES, G. A. C.; PAIVA, R.; HERRERA, R. C.; PAIVA, P. D. O. Micropropagation of Maclura tinctoria L.: an endangered woody species. Revista Árvore, Viçosa, MG, v. 34, n. 1, p. 25-30, 2010.

GRATTAPAGLIA D.; MACHADO, M. A. Micropropagação. In: TORRES, A. C.; CALDAS, L. S.; BUSO, J. A. (Ed.). Cultura de tecidos e transformação genética de plantas. Brasília, DF: EMBRAPA-SPI; EMBRAPA-CNPH. 1998. p. 183-260.
HANDA, L; SAMPAIO, P. DE T. B.; QUISEN, R. Estabelecimento in vitro de explantes de pau-rosa (Aniba rosaeodora Ducke). Acta Amazonica, Manaus, v. 35, n. 1, p. 489-496, 2005.

HEBERLE, M. Propagação in vitro e ex vitro de louro-pardo (Cordia trichotoma (Vell.) Arrabida ex Steudel). 2010. $76 \mathrm{f}$. Dissertação (Mestrado em Engenharia Florestal) - Universidade Federal de Santa Maria, Santa Maria, RS.

HORBACH, M. A.; BISOGNIN, D. A.; KIELSE, P. Q.; KENIA M.; FICK, T. A.; Micropropagação de plântulas de erva-mate obtidas de embriões zigóticos. Ciência Rural, Santa Maria, RS, v. 41, n. 1, p. 113-119, 2011.

HUBNER, H. I.; SILVA, L. V. da; CAPATTI, I.; FUMAGALI, E.; SOUTO, E. R.; GONÇALVES, R. A. C.; OLIVEIRA, A. J. B. Multiplicação in vitro de Aspidosperma ramiflorum Muell. Arg. (Apocynaceae). Acta Scientiarum. Health Sciences, Maringá, v. 29, n. 1, p. 63-66, 2007.

KIELSE, P.; FRANCO, E. T. H.; PARANHOS; J. T.; LIMA, A. P. S. Regeneração in vitro de Parapiptadenia rigida. Ciência Rural, Santa Maria, RS, v. 39, n. 4, p. 1088-1094, 2009.

KOSKY, R. G.; BARRANCO, L. A.; PÉREZ, B. C.; DANIELS, D.; VEJA, M. R.; SILVA, M. F. Trueness-to-type and yield components of the banana hybrid cultivar FHIA-18 plants regenerated via somatic embryogenesis in a bioreactor. Euphytica, Wageningen, v. 150, n. 2, p. 63-68, 2006.

KUBOTA, C.; KOZAI, T. Growth and net photosynthetic rate of Solanum tuberosum in vitro under forced and natural ventilation. HortScience, Alexandria, v. 27, p. 1312-1314, 1992.

LAMEIRA, O. A.; LOPES, S. C.; NOGUEIRA, R. C.; CORDEIRO, I. M. C. C.; PINTO, J. E. B. P.; REIS, L. R. S. Efeito de diferentes concentrações de reguladores de crescimento sobre a micropropagação de mogno (Swietenia macrophylla King) por meio de explantes juvenis. Plan Cell Culture \& Micropropagation, Lavras, v. 1, n. 2, p. 53-58, 2005.

LARRABURU, E. E.; APOSTOLO, N. M.; LLORENTE, B. E. In vitro propagation of pink lapacho: response surface methodology and factorial analysis for optimisation of medium components. International Journal of Forestry Research, Cairo, v. 1, p. 1-9, 2012.

LÉDO, A. da S.; SECA, G. S. V.; BARBOZA, S. B. S. C.; SILVA JUNIOR, J. F. Crescimento inicial de mangabeira (Hancornia speciosa Gomes) em diferentes meios de germinação in vitro. Ciência Agrotécnica, Lavras, v. 31, n. 4, p. 989-993, 2007.

LÉDO, A. S.; SÁ, A. J.; SILVA JUNIOR, J. F.; SILVA, A. V. C.; DINIZ, L. E. C.; LÉDO, C. A. S. Development of in vitro propagation and conservation protocols of the native brazilian mangaba tree. Acta Horticulturae, Leuven, v. 918, p. 177-182, 2011.

LEITZKE, L. N.; DAMIANI, C. R.; SCHUCH, M. W. Meio de cultura, concentração de AIB e tempo de cultivo no enraizamento in vitro de amoreira-preta e framboeseira. Revista Brasileira Fruticultura, Jaboticabal, v. 31, n. 2, p. 582-587, 2009.

LEMOS, E. E. P.; FERREIRA, M. S.; ALENCAR, L. M. C.; OLIVEIRA, J. G. L.; MAGALHÃES, V. S. Micropropagação de clones de banana cv. Terra em biorreator de imersão temporária. Revista Brasileira de Fruticultura, Jaboticabal, v. 23, p. 482-487, 2001. 
LEÓN, E. A. B. Germinação, estabelecimento, regeneração e calogênese in vitro em explantes de açoita cavalo (Luehea divaricata Mart. \& Zucc.). 2010. 61 f. Dissertação (Mestrado em Engenharia Florestal) - Universidade Federal de Santa Maria, Santa Maria, RS.

LLOYD, G.; MCCOWN, B. Commercially feasible micropropagation of mountain laurel,(Kalmia latifolia), by use of shoot tip culture. Combined Proceedings: International Plant Propagator's Society, n. 30, p. 421-427, 1981.

LORENZO, J. C.; GONZALES, B.; ESCALONA, M.; TEISSON, C.; ESPINOSA, P.; BORROTO, C. G. Sugar cane shoot formation in an improved temporary immersion system. Plant Cell, Tissue and Organ Culture, Dordrecht, v. 54, n. 3, p. 197-200, 1998.

MALOSSO, M. G.; BERTONI, B. W.; COPPEDE, J. S.; FRANÇA, S. C.; PEREIRA, A. M. S. Micropropagation and in vitro conservation of Jacaranda decurrens Cham. Journal of Medicinal Plants Research, Nairobi, v. 6, n. 7, p. 1147-1154, 2012.

MANTOVANi, N. C.; FRANCO, E. T. H.; VESTENA, S. Regeneração in vitro de louro-pardo (Cordia trichotoma (Vellozo) Arrabida ex Steudel). Ciência Florestal, Santa Maria, RS, v. 11, n. 2, p. 93-101, 2001.

MANTOVANI, N. C.; GRANDO, M. F.; XAVIER, A.; OTONI, W. C. Resgate vegetativo por alporquia de genótipos adultos de urucum (Bixa orellana L.). Ciência Florestal, Santa Maria, RS, v. 20, n. 3, p.403-410, 2010.

MARUYAMA, E.; ISHII, K.; KINOSHITA, I.; OHBA, K.; SAITO, A. Micropropagation of bolaina blanca (Guazuma crinita Mart.), a fast-growing tree in Amazon region. Journal Forest Research, Ottawa, v. 1, n. 4, p. 211-217, 1996.

MARUYAMA, E.; ISHII, K.; KINOSHITA, I.; OHBA, K.; SAITO, A. Micropropagation of Guazuma crinita mart. by root and petiole culture. In Vitro Cellular \& Developmental Biology: Plant, Wallingford, v. 33, n. 2, p. 131-135, 1997.

MELO, B. Diferentes antioxidantes no controle da oxidação, germinação e desenvolvimento de plântulas na cultura in vitro de embriões da guarirobeira Syagrus oleracea (MART.) BECC. Ciência Agrotécnica, Lavras, v. 25, n. 6, p. 1301-1306, 2001.

MORDOCCO, A. M.; BRUMBLEY, J. A.; LAKSHMANAN, P. Development of a temporary immersion system $\left(\right.$ RITA $\left.^{\circledR}\right)$ for mass production of sugarcane (Saccharum spp. interspecific hybrids). In Vitro Cellular \& Developmental Biology Plant, Wallingford, v. 45, n. 4, p. 450-457, 2009.

MORITZ, A.; DEGENHARDT, J.; DUTRA, L. F.; HANSEL, F. A.; LIMA, B. H. de; FRANCESCHI, C. do R. B.; FRANCISCON, L. Estabelecimento in vitro de Ocotea odorifera, $O$. catharinensis e $O$. porosa. Pesquisa Florestal Brasileira, Colombo, n. 59, p. 37-44, 2009. DOI: $10.4336 / 2009 . p f b .59 .37$

MOTOIKE, S. Y.; SARAIVA, E. S.; VENTRELLA, M. C.; SILVA, C. V.; SALOMÃO, L. C. C. Somatic embryogenesis of Myrciaria aureana (Brazilian grape tree). Plant Cell, Tissue and Organ Culture. Dordrecht, v. 89, p. 75-81. 2007.
MOURA, E. F.; VENTRELlA, M. C.; MOTOIKE, S. Y.; SÁ JÚNIOR, A. Q.; CARVALHO, M.; MANFIO, C. E. Histological study of somatic embryogenesis induction on zygotic embryos of macaw palm (Acrocomia aculeata (Jacq.) Lodd. ex Martius). Plant Cell, Tissue and Organ Culture, Dordrecht, v. 95, p. 175-184. 2008.

MOURA, L. C.; TITON, M.; MIRANDA, N. A.; MOREIRA, T. P.; OLIVEIRA M. L. R. Multiplicação e Alongamento in vitro de vinhático (Plathymenia reticulate). Scientia Forestales, Piracicaba, v. 40, n. 96, p. 499-505, 2012.

MURASHIGE, T.; SKOOG, F. A revised medium for rapid growth and bio assays with tobacco tissue cultures. Physiologia Plantarum, Copenhagen, v. 15, p. 473-497, 1962.

NASCIMENTO, A. C.; PAIVA, R.; ABBADE, L. C.; VARGAS, D. P.; SOARES, F. P. Micropropagação de uvaieira (Eugenia pyriformis Cambess): efeitos do BAP e AIB. Revista Verde, Mossoró, v. 3, n. 2, p. 20-26. 2008a.

NASCIMENTO, A. C.; PAIVA, R.; NOGUEIRA, R. C.; PORTO, J. M. P.; NOGUEIRA, G. F.; SOARES, F. P.; BAP e AIB no cultivo in vitro de Eugenia pyriformis Cambess. Revista Acadêmica: Ciências Agrárias e Ambientais, Curitiba, v. 6, n. 2, p. 223-228. 2008 b.

NASCIMENTO, P. K. V. do. Regeneração in vitro de Parapiptadenia rigida (Bentham) Brenan. 2008. 76 f. Dissertação (Mestrado em Engenharia Florestal) - Universidade Federal de Santa Maria, Santa Maria, RS.

NEPOMUCENO, C. F.; SOUZA, A. P. de; QUEIROZ, S. R. O. D.; PELACANI, C. R.; SANTANA, J. R. F. de. Respostas morfofisiológicas in vitro de plântulas de Anadenanthera colubrina (Vell.) Brenan var. cebil (Griseb) Altschul. Revista Árvore, Viçosa, MG, v. 33, n. 3, p. 481-490, 2009.

NOLETO, L. G.; SILVEIRA, C. E. S. Micropropagação de Copaíba. Revista Biotecnologia, Ciência e Desenvolvimento, Brasília, DF, v. 33, p. 109-120, 2004.

NUNES, E. C.; CASTILHO, C. V.; MORENO, F. N.; VIANA, A. M. In vitro culture of Cedrela fissilis Vellozo (Meliaceae). Plant Cell, Tissue and Organ Culture, Dordrecht, v. 70, n. 3, p. 259-268, 2002.

NUNES, G. P.; SILVA, M. F.; RESENDE, U. M.; SIQUEIRA, J. M. Plantas medicinais comercializadas por raizeiros no centro de Campo Grande, Mato Grosso do Sul. Revista Brasileira de Farmacognosia, Curitiba, v. 13, n. 2, p. 18-27, 2003.

OLIVEIRA, F. F. M.; SILVA, K. M. B.; OLIVEIRA, G. F. de; DANTAS, I. M.; CAMACHO, G. V. Micropropagação de Mimosa caesalpiniaefolia Benth. a partir de segmentos nodais e ápices caulinares. Revista Caatinga, Mossoró, v. 20, n .3, p. 152-159, 2007.

PELEGRINI, L. L.; RIBAS, L. L. F.; ZANETTE, F.; KOEHLER, H. S. Micropropagation of Ocotea porosa (Nees \& Martius) Barroso. African Journal of Biotechnology, Nairobi, v. 10, n. 9, p. 15271523, 2011.

PINTO, F. Calogênese e indução de gemas axilares em mogno (Swietenia macrophylla King). 2012. 87 f. Dissertação (Mestrado em Ciências) - Universidade Federal do Paraná, Curitiba.

PLANO Nacional de Silvicultura com Espécies Nativas e Sistemas Agroflorestais: PENSAF. Brasília, DF: MMA; MAPA; MDA; MCT, 2006. 38 p. 
REIS, I. N. R. S.; LAMEIRA, O. A.; CORDEIRO, I. M. C. C.; CASTRO, C. V. B.; CARNEIRO, A. G. Cultivo in vitro de eixos embrionários de paricá. Ciência Agrotécnica, Lavras, v. 33, n. 1, p. 60-66, 2009.

RIBAS, L. L. F.; ZANETTE, F.; KULCHETSCKI, L.; GUERRA, M. P. Micropropagação de Aspidosperma polyneuron (peroba-rosa) a partir de segmentos nodais de mudas juvenis. Revista Árvore, Viçosa, MG, v. 29, n. 4, p. 517-524. 2005.

ROCHA, S. C.; QUOIRIN, M. Calogênese e rizogênese em explante de mogno (Swietenia macrophylla King) cultivados in vitro. Ciência Florestal, Santa Maria, RS, v. 14, n. 1, p. 91-101, 2004.

ROCHA, S. C. da; QUORIM, M.; RIBAS, L. L. F.; KOEHLER, H. S. Micropropagação de Cabralea canjerana. Revista Árvore, Viçosa, MG, v. 31, n. 1, p. 43-50, 2007.

SÁ, A. J. Avanços na propagação e conservação in vitro da mangabeira (Hancornia speciosa Gomes) nativa da região nordeste. 2009. 81 f. Dissertação (Mestrado em Agrossistemas) Universidade Federal de Sergipe, São Cristovão.

SÁ, A. J.; LÉDO, A. S.; LÉDO, C. A. S.; PASQUAL, M.; SILVA, A. V. C.; JUNIOR, J. F. S.; Sealing and explant types on the mangaba micropropagation. Ciência Agrotécnica, Lavras, v. 36, n. 4, p. 406-414, 2012.

SALDANHA, A. L. M. Protocolo para a propagação in vitro de cedro (Cedrela odorata L.). 2010, 56 f. Dissertação (Mestrado em Agronomia) - Universidade Federal Rural da Amazônia, Belém, PA.

SANTOS, A. L. W.; SILVEIRA, V.; STEINER, N.; VIDOR, M.; GUERRA, M. P. Somatic embryogenesis im parana pine (Araucaria angustifolia (Bert.) O. Kuntze). Brazilian Archives of Biology and Technology, Curitiba, v. 45, n. 1, p. 97-106, 2002.

SANTOS, D. C.; WENDLING, I.; GROSSI, F. Efeito de diferentes combinações de fitorreguladores e vitaminas no desenvolvimento in vitro e ex vitro de Grevillea robusta Cunn. Colombo: Embrapa Florestas, 2004. 6 p. (Embrapa Florestas. Comunicado técnico, 122).

SANTOS, B. R.; PAIVA, R.; NOGUEIRA, R. C.; OLIVEIRA, L. M.; SILVA, D. P. C.; MARTINOTTO, C.; SOARES, F. P.; PAIVA. P. D. O. Micropropagação de pequizeiro (Caryocar brasiliense Camb.). Revista Brasileira de Fruticultura, Jaboticabal, v. 28, n. 2, p. 293-296, 2006.

SANTOS-SEREJO, J. A.; JUNGHANS, T. G.; SOARES, T. L.; SILVA, K. M. Meios nutritivos para micropropagação de plantas. In: SOUSA, A. S.; JUNGHANS, T. G. Introdução à micropropagação de plantas. Cruz das Almas: Embrapa Mandioca e Fruticultura Tropical, 2006. p. 79-98.

SANTOS, D. C.; WENDLING, I. Avaliação de meios de cultura e métodos de desinfestação de explantes de plantas adultas de ervamate. Revista de Biologia e Farmácia, Campina Grande, v. 4, n. 2, p. 34-42. 2010.

SANTOS, J. P.; DAVIDE A. C.; TEIXEIRA, L. A. F.; MELO, A. J. S.; MELO, L. A. Enraizamento de estacas lenhosas de espécies florestais. Cerne, Lavras, v. 17, n. 3, p. 293-301. 2011.

SARTOR, F. R.; ZANOTTI, R. F.; PÔSSA, K. F.; PILON, A. M.; FUKUSHIMA, C. H. Diferentes meios de cultura e antioxidantes no estabelecimento in vitro do jacarandá da Bahia. Bioscience Journal, Uberlândia, v. 29, n. 2, p. 408-411, 2013.

Pesq. flor. bras., Colombo, v. 33, n. 76, p. 439-453, out./dez. 2013
SATO, A., Y.; DIAS, H. C. T.; ANDRADE, L. A. de; SOUZA, V. C. de. Micropropagação de Celtis sp: controle da contaminação e oxidação. Cerne, Lavras, v. 7, n. 2, p. 117-123. 2001.

SCHOTTZ, E. S.; KALIL FILHO, A. N.; TRACZ, A. L.; KOEHLER, H.; RIBAS L. L. F.; QUOIRIN M. Multiplicação in vitro de Swietenia macrophylla King (Meliaceae) a partir de material juvenil. Ciência Florestal, Santa Maria, RS, v. 17, n. 2, p. 109-117, 2007.

SERVIÇO FLORESTAL BRASILEIRO. Sistema Nacional de Informações Florestais: espécies florestais. Disponível em: $<$ http:// www.florestal.gov.br/snif/recursos-florestais/especies-florestais $>$. Acesso em: 07 jul. 2012.

SHIMIZU, J. Y. Estratégia complementar para conservação de espécies florestais ativas: resgate e conservação de ecótipos ameaçados. Pesquisa Florestal Brasileira, Colombo, n. 54, p. 7-35. 2007.

SILVA, J. M. O. D.; OLTRAMARI, A. C.; MARASCHIN, M. PEDROTTI, E. Cultura de embriões imaturos e organogênese: aspectos biotecnológicos da canela sassafrás. Biotecnologia, Ciência e Desenvolvimento. Brasília, DF, n. 20, p. 44-48, 2001.

SILVA, J. A.; LEITE, E. J.; SALOMÃO, A. N.; SANTOS, I. R. I. Banco de germoplasma de espécies florestais nativas do campo experimental Sucupira. Mogno (Swietenia macrophylla King) Meliaceae. Brasília, DF: Embrapa Recursos Genéticos e Biotecnologia, 2004. 50 p. (Embrapa Recursos Genéticos e Biotecnologia. Documentos, 122).

SILVA, L. C.; SCHUCH, M. W.; SOUZA, J. A.; ERIG, A. C.; ANTUNES, L. E. C. Efeito da iluminação e pré-lavagem das brotações de mirtilo cv. Florida no estabelecimento in vitro. Revista Brasileira de Agrociência, Pelotas, v. 13, n. 1, p. 127-129, 2007.

SILVA, T. E. R.; CIDADE, L. C.; ALVIM, F. C.; CASCARDO, J. C. M.; COSTA, M. G. C. Studies on genetic transformation of Theobroma cacao L.: evaluation of different polyamines and antibiotics on somatic embryogenesis and the efficiency of uidA gene transfer by Agrobacterium tumefaciens. Plant Cell Tissue and Organ Culture, Martinus Nijhoff, v. 99, p. 287-298, 2009.

SILVA, T. S. Morfogênese e conservação in vitro de Caesalpinia pyramidalis Tul. 2012. 88 f. Dissertação (Mestrado em Biotecnologia) - Universidade Estadual de Feira de Santana, Feira de Santana.

SILVEIRA, V.; STEINER, N.; SANTOS, A. L. W.; NODARI, R. O.; GUERRA, M. P. Biotechnology tolls in Araucaria angustifolia conservation and improvement: inductive factors affecting somatic embryogenesis. Crop Breeding and Applied Biotechnology, Viçosa, MG, v. 2, n. 3, p. 463-470, 2002.

SKREBSKY, E. C.; NICOLOSO, F. T.; MALDANE, J. Substratos na aclimatização de Pfaffia glomerata (Spreng) Pedersen produzida in vitro sob diferentes doses de sacarose. Ciência Rural, Santa Maria, RS, v. 36, n. 5, p. 1416-1423, 2006.

SOARES, F. P.; PAIVA, R.; ALVARENGA, A. A.; NOGUEIRA, R. C.; EMRICH, E. B.; MARTINOTTO, C. Organogênese direta em explantes caulinares de mangabeira (Hancornia speciosa Gomes). Ciência Agrotecnologia, Lavras, v. 31, n. 4, p. 1048-1053, 2007. 
SOBHA, S.; SUSHAMAKUMARI, S.; THANSEEM, I.; JAYASREE, P. K.; REKHA, K.; JAYASHREE, R.; KALA, R. G.; ASOKAN, M. P.; SETHURAJ, M. R.; DANDEKAR, A. M.; THULASEEDHARAN, A. Genetic transformation of Hevea brasiliensis with the gene coding for superoxide dismutase with FMV 34S promoter. Current Science, New York, v. 85, n. 12, p. 1767-1774, 2003.

SOBROSA, R. C.; CORDER, M. P. M. Efeito do genótipo sobre o potencial para produção de gemas e raízes adventícias em Eucalyptus grandis Hill ex Maiden in vitro. Floresta e Ambiente, Seropédica, v. 10, n. 1, p. 58-68, 2003.

SOUSA, V. A.; AGUIAR, A. V. Programa de melhoramento genético de araucária da Embrapa Florestas: situação atual e perspectivas. Colombo: Embrapa Florestas, 2012. 40 p. (Embrapa Florestas. Documentos, 237).

SOUZA, A. V.; PEREIRA, A. M. S. Enraizamento de plantas cultivadas in vitro. Revista Brasileira de Plantas Medicinais, Botucatu, v. 9, n. 4, p. 103-117. 2007.

SOUZA, L. S.; FIOR, C. S.; SOUZA, P. V. D.; SCHWARZ, S. F. Desinfestação de sementes e multiplicação in vitro de guabijuzeiro a partir de segmentos apicais juvenis (Myrcianthes pungens O.Berg) D. Legrand. Revista Brasileira Fruticultura, Jaboticabal, v. 33, n. 3, p. 691-697, 2011.

TEISSON, C.; ALVARD, D. In vitro production of potato microtubers in liquid medium using temporary immersion. Potato Research, Dordrecht, v. 42, n. 3, p. 499-504, 1999.

TEIXEIRA, D. A. Promoção de enraizamento e indução de resistência sistêmica à ferrugem (Puccinia psidii) e à mancha de Cylindrocladium candelabrum mediadas por rizobactérias em Eucalyptus spp. 2001. 67 f. Tese (Doutorado em Fitopatologia) Universidade Federal de Viçosa, Viçosa, MG.

TEIXEIRA, J. B. Biorreatores. Biotecnologia Ciência e Desenvolvimento, Brasília, DF, v. 24, p. 36-41, 2002.
VIANI, R. A. G.; RODRIGUES, R. R. Sobrevivência em viveiro de mudas de espécies nativas retiradas da regeneração natural de remanescente florestal. Pesquisa Agropecuária Brasileira, Brasília, DF, v. 42, n. 8, p. 1067-1075, 2007.

VILLA, F.; PASQUAL, M.; ASSIS, F. A.; ASSIS, G. A.; ZÁRRAGA, D. Z. A. Micropropagação de duas espécies frutíferas, em meio de cultura DSD1, modificado com fontes de boro e zinco. Ciência e Agrotecnologia, Lavras, v. 33, n. 2, p. 468-472, 2009.

WENDLING, I.; DUTRA, L. F.; GROSSI, F. Produção de mudas de espécies lenhosas. Colombo: Embrapa Florestas. 2006. 54 p. (Embrapa Florestas. Documentos, 130).

WENDLING, I.; BRONDANI, G. E.; BIASSIO, A.; DUTRA, L. F. Vegetative propagation of adult Ilex paraguariensis trees through epicormic shoots. Acta Scientiarum Agronomy, Maringá, v. 35, n. 1, p. 117-125, 2013.

WERNER, E. T.; PESSOTTI, K. V.; LOPES F. P.; CUZZUOL, G. R. F. Indução da calogênese de Caesalpinia echinata Lam. (pau-brasil) in vitro. Revista Brasileira de Biociências, Porto Alegre, v. 5, supl. 2, p. 1053-1055, jul. 2007.

WERNER, E. T.; CUZZUOL, G. R. F.; PESSOTTI, KAMILA, V.; LOPES, F. P.; ROGER, J. A. Controle da calogênese do pau-brasil in vitro. Revista Árvore, Viçosa, MG, v. 33, n. 6, p. 987-996, 2009.

XAVIER A.; WENDLING L.; SILVA, R. L. Silvicultura clonal: princípios e técnicas. 2. ed. Viçosa, MG: Ed. da UFV, 2013. 279 p.

XAVIER, A.; OTONI, W. C.; Aplicações da micropropagação na clonagem de Eucalyptus no Brasil. Agronomía Costarricense, San José, v. 33, n. 2, p. 303-307, 2009.

YAMAZAKI, T.; OYANAGI, H.; FUJIWARA, T.; FUKUMORI, Y. Nitrite reductase from the magnetotactic bacterium Magnetospirillum magnetotacticum: a novel cytochrome-cd(1) with Fe(II)-nitrite oxidoreductase activity. Europen Journal Biochemistry, Berlim, v. 233, n. 2, p. 665-671, 1995. 
